\title{
Ethno-cultural diversity and contemporary national societies
}

A glance at demographic data for European countries reveals that every year international migration contributes to population growth more than natural change (European Commission 2010). On 1 January 2013, foreign-born individuals accounted for $6.7 \%$ of the total population legally residing in the EU-27 countries (Eurostat 2014). According to a demographic projection (Lanzieri 2010), by 2060, persons of all nationalities with at least one foreign-born parent are expected to account for about $33 \%$ of the EU-27 population. As national societies, within Europe and elsewhere, are deemed to become increasingly diverse in ethnocultural, religious, and racial terms, the question which comes to the fore is how people can live together in/with/through diversity.

Although academic scholarship has offered important insights into the ways that migrants negotiate their everyday lives within receiving societies (Bailey 2000; Fortier 2000; Kastoryano 2002; Kumsa 2005; Ho 2006; Brah 2007; Skrbiš et al. 2007; Cagliotti 2008; Getrich 2008; Mavroudi 2008; Nagel \& Staeheli 2008; Nelson \& Hiemstra 2008; Zevallos 2008), the general tendency has been to eschew the national dimension in favour of cosmopolitan (Archibugi et al. 1998; Cheah \& Robbins 1998; Beck 2000; Featherstone 2002; Nava 2002; Vertovec \& Cohen 2002), transnational (Basch et al. 1994; Hannerz 1996; Portes 1996; Glick Schiller 1997; Robinson 1998; Vertovec 1999; Kivisto 2001; International Migration Review 2003), or 'local' (Amin 2002; Valentine 2008; Matejskova \& Leitner 2011; Leitner 2012; Closs Stephens 2013) perspectives. Implicit in many of these accounts is a treatment of the nation as a site of exclusion, marginalization, and oppression of diversity, broadly understood (Antonsich 2009; Mavroudi 2010).

Thus, the alternative scales of socio-spatial life (cosmopolis, transnational networks, micro-publics of everyday life, the city, etc.) have been both investigated and celebrated as spaces where diversity can be more fully expressed, performed, and lived. This treatment, though, seems to ignore two points: first, there is nothing ipso facto progressive about these spaces, which in fact might equally be populated by the discourses and practices of marginalization and discrimination (Castree 2004); second, the nation in practice is not necessarily a homogenizing singular, stable, coherent identity (Agnew 1994). On the contrary, the nation as a concept and practice has continuously re-invented itself to meet the mutated socio-economic conditions of collective life (Baumann 2004). Accordingly, some influential scholars have reaffirmed the importance of the nation even in the age of migration (Brubaker 2004, 2010; Calhoun 2007, 2008; Hedetoft 2011).

Yet, these and other accounts have only rarely been accompanied by an investigation into whether and how the institutional and social imaginary of the nation has been re-written to face the new international mobility and increased ethno-cultural pluralism of its populace. We would argue that it is important to examine the nation as an unstable, plural construct, which has the capacity to exclude, include, and change. As a dynamic notion, it can therefore be further interrogated, in order to examine in detail the ways in which it is being appropriated, contested and made meaningful in embodied, material and symbolic ways. Above all, if one agrees on the need for nations to be inclusive (Mavroudi 2010), it is necessary to closely explore the complex ways in which the nation intersects with everyday life and, in particular, the ways in which the nation can be both exclusive and inclusive. It is the purpose of this special issue to reflect on how the nation is re-signified in order to deal with the ethno-cultural transformation of contemporary societies. We stress the importance of paying attention to the scale of the nation without making assumptions about its oppressive or homogenising tendencies. Instead, there is a need to deconstruct and dissect the nation, both as a notion and practice, exactly at a time when it faces enduring mistrust in scholarly work dealing with diversity and change (Antonsich 2009). We contend that the national scale is an important one to hold onto even as it interacts with other scales; it is a necessary scale, which still permeates and affects people's lives and identities in myriad ways, and the specific practices, negotiations and processes that occur as a result need to be examined.

The articles gathered here originate from two sessions, convened respectively in London (The ReMaking of the National in the Age of Migration, An- 
nual Meeting of the Royal Geography Society with the Institute of British Geographers, 28 August 2013) and in Rome (Ethno-Cultural Diversity and the Question of the National, IV EUGEO Congress, 7 September 2014). Overall we believe that the five articles nicely address the question of the national in the context of increasing ethno-cultural diversity from a variety of geographical contexts and thematic lines, thus offering a rich empirical field from which to scrutinize the ways in which the national continues to play a major role in shaping societal life and encounters among diverse people.

The first article, by Tania Rossetto, critically discusses the narrative of the city/nation divide. As mentioned above, this divide is indeed central to many scholarly investigations into ethno-cultural diversity. In the words of Rossetto, while the city is conceptualized as dynamic, lived, and open, the nation is portrayed as fixed, abstract, and constraining. By focusing on a photographic performance project in Padua, Italy, which involved young migrants as active participants, Rossetto rebuffs this divide which she calls the "tale of two scales". The kind of nation she is putting forward, through the lived performances of migrants, is one which is agency-centred, pragmatic, non-discursive, progressive, emplaced, dynamic and experiential. It is a nation which challenges the cultural singularity of nationalistic accounts, often dismissed by scholars as abstract and ideological. This is a key move which allows us to see the interplay of local and national rather than their juxtaposition. Accordingly, Rossetto argues for a transcalar study of the migratory experience, one which simultaneously takes into consideration the coexistence and interpenetration of a plurality of scales. Drawing on Amin (2012), she then suggests that the "urban unconscious", or the sense of being together in the urban frame, can equally be translated into a "national unconscious", or the sense of being together in the national frame. This being together, according to Rossetto, can be conceptualized along the lines suggested for the city by Coward (2012), as a space "between us". The nation then, for Rossetto, might be best conceptualized as a frame for shared existence rather than an identity bond $-\mathrm{a}$ terrain of communality post-identity as also suggested by other authors (Antonsich 2009).

The second article, by Joseph Downing, is closely related to the intervention by Rossetto. In fact, it also engages closely with the local/national divide. However, it adopts a different entry point, both disciplinary and methodologically. Being rooted in nationalism studies, the article privileges an institutional perspective. The focus here is on the local policies which both Lyon and Marseille have adopted to cater for the diversity of their population. Moving away from the French republican tradition, blind to any difference of its citizens, Lyon and even more so Marseille have put in place a series of measures, co-opting local organisations as well, which aim to recognize and include postmigration minority groups living in these two cities. Echoing the works of Confino and Skaria (2002) and Jones and Fowler (2007), among others, Downing reasserts the key point that the nation does not live only at the national scale, but can be found at the local scale as well. As Downing observes, the local appropriates the nation in such a way that this latter has various local meanings and, in turn, local processes play a major role in both representing and reproducing the nation. Through a rich and diversified account of difference-orientated policies and initiatives in Lyon and Marseille, Downing makes the interesting point that a shift in the ways the national deals with diversity might not necessarily come from a coherent directive of the central government. Rather, it is the local and its actors which might re-work the national and open it up to a more plural understanding about the diversity which composes it. This stresses the importance of bottom up nationalism and the agency involved in constructing the nation, as a flexible and dynamic process.

The third article, by Anna Gawlewicz, also addresses a case study in which, like in Rossetto for Italy, the encounter with diversity is a relatively recent experience. Gawlewicz focuses on the perceptions of diversity held by Polish migrants living in the UK, reflecting on how these perceptions impact on the migrants' notion of Polishness. Like Rossetto, Gawlewicz also adopts a geographical disciplinary perspective. Relying on individual interviews conducted in a northern English city, Leeds, Gawlewicz explores the multifarious ways in which Polish migrants talk of/about their lived experience of difference in terms of ethnicity, religion, class, age, gender, sexuality and disability. The picture which emerges is one which she labels, after Kurczewska (2003) and Marciniak (2009), the "inferiority-superiority" complex. In other words, when it comes to comparing how difference is lived in Britain and in Poland, the latter is constructed as inferior. Yet, when it comes to family values, Poland emerges as superior to Brit- 
ain. In this sense, the article suggests how nationness, far from a fixed and stable category, is a very malleable notion, which can be activated differently in different discursive contexts.

The two remaining articles take us across the Atlantic, to North America and Chile respectively. They both rely on anthropologically-informed ethnographical research. The article by Ashutosh examines the role of nations and nationalism amongst South Asian migrants in Toronto and New York. Ashutosh's argument is that, in the age of migration, the nation is caught between two opposite logics: on the one hand, the nation is reasserted in its exclusive features via the state projects of managing diversity and discourses on immigration; on the other hand, this very idea of a clearly and permanently delineated nation is challenged by migrants' complex transnational practices. Everyday interactions and experiences of South Asian migrants living in Toronto transform the meaning of the nation, by constantly transgressing its borders. In this sense, Ashutosh, echoing Walton-Roberts and Pratt (1995), suggests that international migration exposes the limits of national imaginaries and entails a reconstitution and reworking of identities. This process, though, is also surrounded by noticeable ambiguity. Migrant practices, in fact, ranging from the prosaic to the spectacular, challenge as well as reinforce the contours of national belonging and community. Thus, the analytic work that has to be done is to attend to the multiple and conflicting spaces and scales through which nationess manifests itself.

The focus of the final article by Imilan is also closely related to this understanding about nationess as variously performed by migrants. Grounded in ethnographic work conducted among Peruvian migrants working and living in Santiago de Chile, the article shows how a sense of nationness can be mobilized through the very mundane practice of food production and consumption. Peruvian cuisine is becoming very popular world-wide. Peruvian migrants living in Chile have capitalized on this development, which offers them a unique way of integrating socially and economically within Chilean society by emphasising their national origin as a positive and distinguishing feature. Imilan's article thus explores the performativity of Peruvianness through gastronomic practices, which then become spaces of communication and recognition of diversity. These culinary practices point to the intersection of local, national and transnational scales, as well as to a form of popular, non-he- gemonic globalization (Lins Ribeiro 2009), providing a successful way for migrants to negotiate their national belonging.

Taken together, these case studies demonstrate how the nation is being deconstructed and (re)articulated through everyday practices and people's agency. As a plural notion, it has the capacity to transform, and to include those once deemed to be too different. Yet, challenges remain in terms of the ways in which the nation continues to exclude and oppress. At the same time, continued research is needed on the ways the nation can be made more inclusive, in both top-down and bottom-up ways, as it deals with demographic change.

Marco Antonsich, Loughborough University, United Kingdom. E-mail: M.Antonsich@lboro.ac.uk

Elizabeth Mavroudi, Loughborough University, United Kingdom. E-mail: E.mavroudi@lboro.ac.uk

\section{REFERENCES}

Agnew J 1994. The territorial trap: the geographical assumptions of international relations theory. Review of International Political Economy 1: 1, 53-80. http://dx.doi.org/10.1080/09692299408434268.

Amin A 2002. Ethnicity and the multicultural city: living with diversity. Environment and Planning A 34: 6, 959-980. http://dx.doi.org/10.1068/a3537.

Amin A 2012. Land of strangers. Polity Press, Cambridge-Malden, MA.

Antonsich M 2009. On territory, the nation-state and the crisis of the hyphen. Progress in Human Geography 33: 6, 789-806. http://dx.doi.org/10.1177/0309132508104996.

Archibugi D, Held D \& Köhler M (eds). 1998. Reimagining political community: studies in cosmopolitan democracy. Stanford University Press, Stanford, CA.

Bailey B 2000. Language and negotiation of ethnic/ racial identity among Dominican Americans. Language in Society 29:4, 555-582. http://dx.doi.org/10.1017/S0047404500004036.

Basch L, Glick Schiller N \& Szanton Blanc C (eds). 1994. Nations unbound: transnational projects, postcolonial predicaments, and deterritorialized nation-states. Gordon \& Breach, New York.

Baumann G 2004. Introduction: nation-states, schools and civil enculturation. In Schiffauer W, Baumann G, Kastoryano R \& Vertovec S (eds). Civil enculturation, 1-20. Berghahn Books, New York.

Beck U 2000. The cosmopolitan perspective: sociology of the second age of modernity. British Journal of Sociology 51: 1, 79-106.

http://dx.doi.org/10.1111/j.1468-4446.2000.00079.x. 
Brah A 2007. Travels in negotiations: difference, identity, politics. Journal of Creative Communications 2: $1 \& 2,245-256$. http://dx.doi.org/10.1177/097325860700200212.

Brubaker R 2004. In the name of the nation: reflections on nationalism and patriotism. Citizenship Studies 8: 2, 115-127.

http://dx.doi.org/10.1080/1362102042000214705.

Brubaker R 2010. Migration, membership, and the modern nation-state: internal and external dimensions of the politics of belonging. Journal of Interdisciplinary History 41: 1, 61-78. http://dx.doi.org/10.1162/jinh.2010.41.1.61.

Cagliotti DL 2008. Elite migrations in modern Italy: patterns of settlement, integration and identity negotiation. Journal of Modern Italian Studies 13: 2, 141-151. http://dx.doi.org/10.1080/13545710802010917.

Calhoun C 2007. Nations matter: citizenship, solidarity and the cosmopolitan dream. Routledge, London.

Calhoun C 2008. Cosmopolitanism and nationalism. Nations and nationalism 14: 3, 427-448. http://dx.doi.org/10.1111/j.1469-8129.2008.00359.x.

Castree N 2004. Differential geographies: place, indigenous rights and 'local' resources. Political Geography 23: 2, 133-167. http://dx.doi.org/10.1016/j.polgeo.2003.09.010.

Cheah P \& Robbins B (eds). 1998. Cosmopolitics: thinking and feeling beyond the nation. University of Minnesota Press, Minneapolis.

Closs Stephens A 2013. The persistence of nationalism. From imagined communities to urban encounters. Routledge, London.

Confino A \& Skaria A 2002. The local life of nationhood. National Identities 4:1, 7-24. http://dx.doi.org/10.1080/14608940120115657.

Coward M 2012. Between us in the city: materiality, subjectivity, and community in the era of global urbanization. Environment and Planning D: Society and Space 30: 3, 468-481. http://dx.doi.org/10.1068/d21010.

European Commission 2010. Demographic report. Directorate-general for employment, social affairs and inclusion and Eurostat. The Statistical Office of the European Union, Bruxelles.

Eurostat 2014. Migration and migrant population statistics. Bruxelles, Eurostat. <http://epp.eurostat. ec.europa.eu/statistics_explained/index.php/Migration_and_migrant_population_statistics $>$

Featherstone M 2002. Cosmopolis: an introduction. Theory, Culture \& Society 19: 1-2, 1-16. http://dx.doi.org/10.1177/026327640201900112

Fortier A-M 2000. Migrant belongings. Memory, space, identity. Berg, Oxford.

Getrich CM 2008. Negotiating boundaries of social belonging. Second-generation Mexican youth and the immigrant rights protests of 2006. American Behavioral Scientist 52: 4, 533-556. http://dx.doi.org/10.1177/0002764208324605.

Glick Schiller N 1997. The situation of transnational studies. Identities 4: 2, 155-166. http://dx.doi.org/10.1080/1070289X.1997.9962587.
Hannerz U 1996. Transnational connections: culture, people, places. Routledge, London.

Hedetoft U 2011. Is nationalism and anachronism? Notes on the mutations of national idealism in a global age. In Barrett M, Flood C \& Eade J (eds). Nationalism, ethnicity, citizenship: multidisciplinary perspectives, 13-34. Cambridge Scholars Publishing, Newcastle upon Tyne.

Ho EL 2006. Negotiating belonging and perceptions of citizenship in a transnational world: Singapore, a cosmopolis? Social \& Cultural Geography 7: 3, 385-401. http://dx.doi.org/10.1080/14649360600715086.

International Migration Review 2003. Special issue on transnational migration. International Migration Review 37: 3. http://dx.doi.org/10.1111/j.1747-7379.2003.tb00150.x.

Jones R \& Fowler C 2007. Placing and scaling the nation. Environment and Planning D 25:2, 332354. http://dx.doi.org/10.1068/d68j.

Kastoryano R 2002. Negotiating identities: states and immigrants in France and Germany. Princeton University Press, Princeton.

Kivisto P 2001. Theorizing transnational immigration: a critical review of current efforts. Ethnic and Racial Studies 24: 4, 549-577. http://dx.doi.org/10.1080/01419870120049789.

Kumsa MK 2005. Between home \& exile: dynamics of negotiating be-longing among young Oromos living in Toronto. In Tettey W \& Puplampu KP (eds). The African diaspora in Canada: Negotiating identity \& belonging, 175-203. Calgary University Press, Calgary.

Kurczewska J 2003. What is likely to happen to Polish collective consciousness after accession to the European Union? Polish Sociological Review 1, 83-92.

Lanzieri G 2010. Fewer, older and multicultural? A projection of the populations of the European Union Member States by foreign/national background. European Population Conference, Vienna, 1-4 September.

Leitner H 2012. Spaces of encounters: immigration, race, class, and the politics of belonging in small-town America. Annals of the Association of American Geographers 102: 4, 828-846. http://dx.doi.org/10.1080/00045608.2011.601204.

Lins Ribeiro G 2009. La globalización popular y el sistema mundial no-hegemónico. Nueva Sociedad 241, 36-62.

Marciniak K 2009. Post-socialist hybrids. European Journal of Cultural Studies 12: 2, 173-190. http://dx.doi.org/10.1177/1367549409102424.

Matejskova T \& Leitner H 2011. Urban encounters with difference: the contact hypothesis and immigrant integration projects in eastern Berlin. Social \& Cultural Geography 12: 7, 717-741. http://dx.doi.org/10.1080/14649365.2011.610234.

Mavroudi E 2008. Palestinians and pragmatic citizenship: negotiating relationships between citizenship and national identity in diaspora. Geoforum 39: 1, 307-318. 
http://dx.doi.org/10.1016/j.geoforum.2007.07.001 .

Mavroudi E 2010. Nationalism, the nation and migration: searching for purity and diversity. Space and Polity 14: 3, 219-233.

http://dx.doi.org/10.1080/13562576.2010.532951.

Nagel C \& Staeheli LA 2008. Integration and the negotiation of 'here' and 'there': the case of British Arab activists. Social \& Cultural Geography 9: 4, 415-430. http://dx.doi.org/10.1080/14649360802069019.

Nava M 2002. Cosmopolitan modernity: everyday imaginaries and the register of difference. Theory, Culture \& Society 19: 1-2, 81-99. http://dx.doi.org/10.1177/026327640201900104.

Nelson L \& Hiemstra N 2008. Latino immigrants and the renegotiation of place and belonging in small town America. Social \& Cultural Geography 9: 3, 319-342. http://dx.doi.org/10.1080/14649360801990538 .

Portes A 1996. Global villagers: the rise of transnational communities. American Prospect 25, 74-77.

Robinson WI 1998. Beyond nation-state paradigms: globalization, sociology, and the challenge of transnational studies. Sociological Forum 13: 4, 561-594. http://dx.doi.org/10.1023/A:1022806016167.

Skrbiš Z, Baldassar L \& Poynting S 2007. Introduction negotiating belonging: Migrations and generations.
Journal of Intercultural Studies 28: 3, 261-269. http://dx.doi.org/10.1080/07256860701429691.

Vertovec S 1999. Conceiving and researching transnationalism. Ethnic and Racial Studies 22: 2, 447462.http://dx.doi.org/10.1080/014198799329558.

Vertovec S \& Cohen R (eds). 2002. Conceiving cosmopolitanism: theory, context, and practice. Oxford University Press, Oxford.

Valentine G 2008. Living with difference: reflections on geographies of encounter. Progress in Human Geography 32: 3, 323-337. http://dx.doi.org/10.1177/0309133308089372.

Walton-Roberts M \& Pratt G 1995. Mobile modernities: a South Asian family negotiates immigration, gender and class in Canada. Gender, Place and Culture 12: 2, 173-195.

http://dx.doi.org/10.1080/09663690500094823.

Zevallos Z 2008. 'You have to be Anglo and not look like me': identity and belonging among young women of Turkish and Latin American backgrounds in Melbourne, Australia. Australian Geographer 39: 1, 21-43.

http://dx.doi.org/10.1080/00049180701877410. 